\title{
Systematic Review: Comparative Effectiveness of Angiotensin- Converting Enzyme Inhibitors and Angiotensin II Receptor Blockers for Treating Essential Hypertension
}

David B. Matchar, MD; Douglas C. McCrory, MD, MHS; Lori A. Orlando, MD, MHS; Manesh R. Patel, MD; Uptal D. Patel, MD; Meenal B. Patwardhan, MD, MHSA; Benjamin Powers, MD; Gregory P. Samsa, PhD; and Rebecca N. Gray, DPhil

Background: The relative effectiveness of angiotensin-converting enzyme (ACE) inhibitors and angiotensin II receptor blockers (ARBs) for lowering blood pressure is unknown.

Purpose: To compare the benefits and harms of ACE inhibitors versus $A R B s$ for treating essential hypertension in adults.

Data Sources: MEDLINE (1966 to May 2006), the Cochrane Central Register of Controlled Trials (Issue 2, 2006), and selected reference lists were searched for relevant English-language trials. The MEDLINE search was updated to August 2007 to identify head-tohead trials that reported blood pressure outcomes and major cardiovascular events.

Study Selection: 61 clinical studies that directly compared ACE inhibitors versus ARBs in adult patients with essential hypertension, reported an outcome of interest, lasted at least 12 weeks, and included at least 20 patients.

Data Extraction: A standardized protocol with predefined criteria was used to extract data on study design, interventions, population characteristics, and outcomes; evaluate study quality and applicability; and assess the strength of the body of evidence for key outcomes.

Data Synthesis: ACE inhibitors and ARBs had similar long-term effects on blood pressure (50 studies; strength of evidence, high).
No consistent differential effects were observed for other outcomes (few studies reported long-term outcomes), including death, cardiovascular events, quality of life, rate of single antihypertensive agent use, lipid levels, progression to diabetes, left ventricular mass or function, and kidney disease. Consistent fair- to good-quality evidence showed that ACE inhibitors were associated with a greater risk for cough. There were fewer withdrawals due to adverse events and greater persistence with therapy for ARBs than for ACE inhibitors, although this evidence was not definitive. Patient subgroups for whom ACE inhibitors or ARBs were more effective, associated with fewer adverse events, or better tolerated were not identified.

Limitations: Few studies involved a representative sample treated in a typical clinical setting over a long duration, treatment protocols had marked heterogeneity, and substantive amounts of data about important outcomes and patient subgroups were missing.

Conclusion: Available evidence shows that ACE inhibitors and ARBs have similar effects on blood pressure control, and that ACE inhibitors have higher rates of cough than ARBs. Data regarding other outcomes are limited.

Ann Intern Med. 2008;148:16-29.

www.annals.org

For author affiliations, see end of text.
$M$ ore than 65 million U.S. adults-approximately one third-have hypertension. In addition to being the leading attributable risk factor for death throughout the world (1), hypertension results in substantial illness due to its effect on several target organs, including the brain, eyes, heart, arteries, and kidneys.

Despite the high rate of morbidity and mortality attributable to hypertension, control remains suboptimal (2). In addition to several effective nonpharmacologic interventions, many individuals require antihypertensive medication to lower blood pressure and often require several med-

See also:

Print

Editors' Notes . . . . . . . . . . . . . . . . . . . . . . 17

Editorial comment. . . . . . . . . . . . . . . . . 76

Related article. . . . . . . . . . . . . . . . 30

Web-Only

Appendixes

CME quiz

Conversion of graphics into slides ications together (2). Among the most common of the many choices in antihypertensive therapy are those aimed at inhibiting the renin-angiotensin-aldosterone (renin) system. Currently, renin system inhibitors include angiotensin-converting enzyme (ACE) inhibitors and angiotensin II receptor blockers (ARBs).

Although clinicians regard ACE inhibitors and ARBs as effectively equivalent, it is not clear whether this is appropriate. For example, ACE inhibitors do not entirely block production of angiotensin II because of other, unaffected converting enzymes. Also, ACE inhibitors are associated with well-known adverse events not shared by ARBs, including cough (estimated incidence, 5\% to 20\%) and the possibly related phenomenon of angioedema (estimated incidence, $0.1 \%$ to $0.2 \%$ ) (3). Although both ACE inhibitors and ARBs are highly effective in lowering blood pressure among patients with essential hypertension $(4,5)$, their comparative effectiveness and the relative advantages and disadvantages of ACE inhibitors versus ARBs are unknown.

This review summarizes the evidence on the comparative long-term benefits and harms of ACE inhibitors versus ARBs for treating essential hypertension in adults. The full technical report was commissioned by the Agency for Healthcare Research and Quality (6).

$16 \mid \odot 2008$ American College of Physicians 


\section{Methods}

We developed and followed a standardized protocol for all steps of the review.

\section{Data Sources and Searches}

We searched MEDLINE (1966 to week 3 of May 2006) and the Cochrane Central Register of Controlled Trials (Issue 2, 2006) for studies published in English after 1988, using terms for drug interventions, hypertension, and study design. We also reviewed bibliographies submitted by pharmaceutical companies to the Scientific Resource Center for the Agency for Healthcare Research and Quality's Effective Health Care Program, reference lists of relevant review articles, and citations identified by reviewers of the draft report. For the current review, we updated our MEDLINE search to August 2007 to identify new headto-head trials that reported blood pressure outcomes and major cardiovascular events. Results from the newly identified studies (7-21) were consistent with the evidence described in the full technical report and are not presented here.

\section{Study Selection}

We included comparative clinical studies of any design (including randomized, controlled trials and nonrandomized, controlled trials; cohort studies; and case-control studies) that provided direct comparisons of ACE inhibitors versus $A R B s$ at 12 weeks or more after the initial intervention. In addition to simple comparisons of a single ACE inhibitor versus a single ARB, we included studies with "grouped" comparisons (such as a specific ARB versus "ACE inhibitors" or unspecified "ARBs" versus unspecified "ACE inhibitors") and comparisons in which the same drug was administered with an ACE inhibitor versus that drug with an ARB (for example, losartan and hydrochlorothiazide vs. enalapril and hydrochlorothiazide). We excluded studies with comparisons in which the drugs administered with an ACE inhibitor differed from those administered with an ARB (for example, enalapril and manidipine vs. irbesartan and hydrochlorothiazide). We included studies with treatment protocols that permitted the addition of other antihypertensive medications during the trial, provided that the co-intervention protocols were the same in the ACE inhibitor and ARB treatment groups. Outcomes we considered included blood pressure control, adherence, quality of life, several intermediate outcomes, and harms. We excluded studies with fewer than 20 total patients in the ACE inhibitor and ARB treatment groups and focused on studies of adults ( $\geq 18$ years of age) with essential hypertension, as defined by the study authors.

We also evaluated studies of ARBs versus other (nonACE inhibitor) comparators and ACE inhibitors versus other (non-ARB) comparators, which were to be considered in case too few direct head-to-head trials were identified for outcomes of interest. Appendix 1 (available at www.annals.org) contains the details of how we identified and reviewed indirect comparison studies.

\section{Context}

Are angiotensin-converting enzyme (ACE) inhibitors or angiotensin II receptor blockers (ARBs) more effective for treating essential hypertension?

\section{Contribution}

This systematic review of trials that directly compared ACE inhibitors and ARBs in adults with essential hypertension found good evidence that the agents had similar longterm effects on blood pressure. There were no consistent differential effects for mortality, cardiovascular events, progression to diabetes, left ventricular function, or kidney disease. Cough was more frequent with ACE inhibitors than ARBs.

\section{Implication}

Both ACE inhibitors and ARBs have similar effects on blood pressure and may not have differential effects on other clinical outcomes, although ACE inhibitors do cause cough more often than ARBs.

\section{- The Editors}

\section{Data Extraction and Quality, Applicability, and Strength of Evidence Assessments}

One author extracted data from each study, which were confirmed by another author. Extracted information included study design; interventions; population characteristics; recruitment setting; inclusion and exclusion criteria; numbers of participants screened, eligible, enrolled, and lost to follow-up; and results for each outcome.

We used predefined criteria adapted from those developed by the U.S. Preventive Services Task Force (22) and the Centre for Reviews and Dissemination in the United Kingdom (23) to assess the quality of individual studies as good, fair, or poor, and we noted important limitations on internal validity for studies rated as fair or poor. The applicability of individual studies was assessed by noting the most important potential limitations (up to 3) in a study's applicability from among the list described by Rothwell (24), as adapted by the Scientific Resource Center (Appendix 2, available at www.annals.org). Quality and applicability assessments are detailed for individual studies in the evidence tables included in the full report (6). Finally, we assessed the strength of the body of evidence for each key question as high, moderate, low, or very low by using the Grading of Recommendations, Assessment, Development, and Evaluation (GRADE) framework (25).

\section{Data Synthesis and Analysis}

Given that many studies did not have the statistical power to determine equivalence for relevant outcomes, we considered pooling (without regard to the specific drug within the ACE inhibitor or ARB class) to overcome a type II error. In evaluating direct comparison studies for potential data synthesis, we primarily considered clinical homogeneity. In general, we considered groups of studies as suit-

\footnotetext{
1 January 2008 Annals of Internal Medicine $\mid$ Volume $148 \cdot$ Number $1 \mid \mathbf{1 7}$
} 
able for quantitative synthesis when we identified at least 4 clinically and relatively similar studies that assessed the same outcome. We used additional and more detailed criteria to determine suitability for pooling of indirect comparisons, as such comparisons are tenuous (Appendix 1, available at www.annals.org). We did not attempt to pool direct and indirect comparison studies in a single analysis, primarily because we did not identify a sufficient number of clinically similar indirect comparison studies to analyze.

When we pooled studies, we used the random-effects model for the primary analysis and the fixed-effect model for sensitivity analysis. We stratified analyses by study design, separating randomized, controlled trials from observational studies. We performed all analyses by using Comprehensive Meta-analysis, version 2 (Biostat, Englewood, New Jersey). For count outcomes, we calculated summaries of the relative effect (odds ratios) and absolute effect (risk difference). We chose the Peto method for analyzing data on cough and withdrawals due to adverse events because event rates were low and treatment groups were not substantially imbalanced, conditions under which this method is the least biased and most powerful (26). This method also allows inclusion of studies with zero events in 1 group with no continuity correction. For data on rates of successful monotherapy, we used risk differences because event rates were high, which makes the assumption of a constant odds ratio unreasonable.

\section{Role of the Funding Source}

The Agency for Healthcare Research and Quality formulated the initial study questions and reviewed and commented on planned methods, data analysis, and the draft report. The funding source did not participate in the search of the literature, determination of study eligibility, or evaluation of individual studies.

\section{RESULTS}

Of 1185 citations, 69 reports (61 distinct studies) directly compared ACE inhibitors with ARBs (Figure 1). Forty-seven studies were randomized, controlled trials; 1 was a nonrandomized, controlled trial; 9 were retrospective cohort studies; 2 were prospective cohort studies; 1 was a cross-sectional cohort study; and 1 was a case-control study. Table 1 shows the numbers of studies that compared different agents. Enalapril was the most frequently studied ACE inhibitor (24 studies), and losartan the most frequently studied ARB (19 studies). Most studies were relatively short-term; 19 followed patients for 12 weeks, and 21 followed patients between 12 weeks and 6 months. Most studies excluded patients with secondary causes of hypertension, as well as patients with recent acute events, such as myocardial infarction or stroke. Table 2 summarizes the number and quality scores of reviewed studies, by outcome assessed.

Figure 1. Study flow diagram.

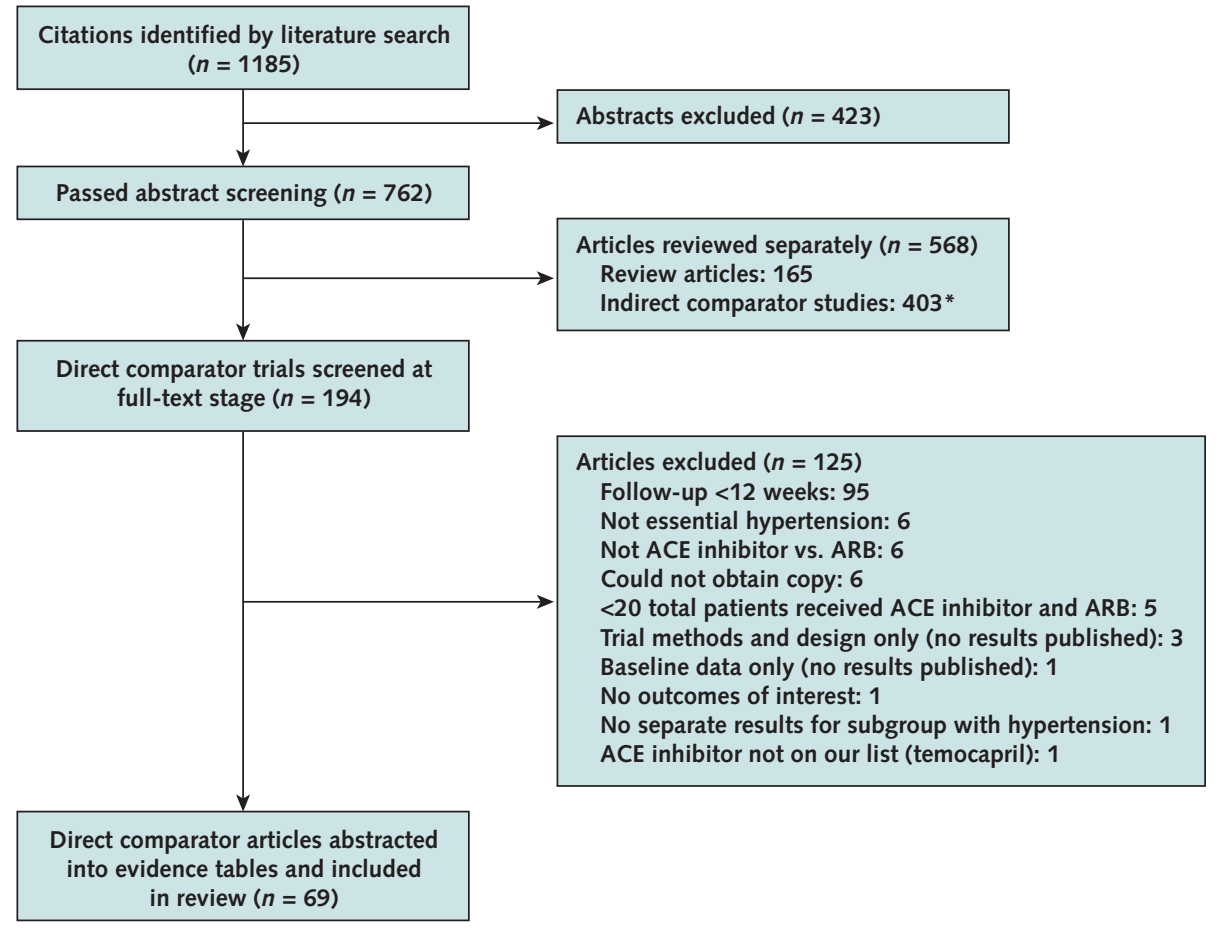

*See Appendix 1 (available at www.annals.org). ACE = angiotensin-converting enzyme; ARB = angiotensin II receptor blocker.

$18 \mid 1$ January 2008 Annals of Internal Medicine $\mid$ Volume $148 \bullet$ Number 1 
Table 1. Number of Included Studies and Publications Evaluating Various Treatment Comparisons*

\begin{tabular}{|c|c|c|c|c|c|c|c|c|c|}
\hline \multirow{2}{*}{$\begin{array}{l}\text { ACE } \\
\text { Inhibitors }\end{array}$} & \multicolumn{9}{|c|}{ ARBs } \\
\hline & Unspecified & $\begin{array}{l}\text { Candesartan } \\
\text { Cilexetil }\end{array}$ & Eprosartan & Irbesartan & Losartan & $\begin{array}{l}\text { Olmesartan } \\
\text { Medoxomil }\end{array}$ & Telmisartan & Valsartan & Total \\
\hline Unspecified & $9(11)$ & $1(1)$ & 0 & $2(2)$ & $2(2)$ & 0 & 0 & 0 & $14(16)$ \\
\hline Benazepril & 0 & 0 & 0 & 0 & 0 & 0 & 0 & 0 & 0 \\
\hline Captopril & 0 & 0 & 0 & 0 & $2(2)$ & 0 & 0 & 0 & $2(2)$ \\
\hline Enalapril & 0 & $4(4)$ & $2(6)$ & $4(4)$ & $10(12)$ & 0 & $3(3)$ & $1(1)$ & $24(30)$ \\
\hline Fosinopril & 0 & 0 & 0 & $2(2)$ & $1(1)$ & 0 & 0 & 0 & $3(3)$ \\
\hline Lisinopril & 0 & $4(4)$ & 0 & 0 & 0 & 0 & $1(1)$ & $3(3)$ & $8(8)$ \\
\hline Moexipril & 0 & 0 & 0 & 0 & 0 & 0 & 0 & 0 & 0 \\
\hline Perindopril & 0 & $1(1)$ & 0 & 0 & $1(1)$ & 0 & $2(2)$ & 0 & $4(4)$ \\
\hline Quinapril & 0 & 0 & 0 & 0 & $2(2)$ & 0 & 0 & 0 & $2(2)$ \\
\hline Ramipril & 0 & 0 & 0 & 0 & 0 & 0 & $3(3)$ & 0 & $3(3)$ \\
\hline Trandolapril & 0 & 0 & 0 & 0 & $1(1)$ & 0 & 0 & 0 & $1(1)$ \\
\hline Total & $9(11)$ & $10(10)$ & $2(6)$ & $8(8)$ & $19(21)$ & 0 & $9(9)$ & $4(4)$ & - \\
\hline
\end{tabular}

* Data are reported as number of studies (number of publications). ACE $=$ angiotensin-converting enzyme; ARB $=$ angiotensin II receptor blocker.

\section{Comparative Effectiveness for Controlling Blood Pressure and Improving Cardiovascular Outcomes and Risk}

Angiotensin-converting enzyme inhibitors and ARBs seem to have similar long-term effects on blood pressure in individuals with essential hypertension.

Because there were too few deaths or major cardiovascular events in the included studies, we could not discern any differential effect of ACE inhibitors versus ARBs for these critical outcomes. Likewise, ACE inhibitors and ARBs exhibited no consistent differential effects on several potentially important risk factors, including lipid levels, progression to type 2 diabetes mellitus, markers of carbohydrate metabolism or diabetes control, measures of left ventricular mass or function, and progression of renal disease (based on creatinine level, glomerular filtration rate, or proteinuria). Relatively few studies assessed these outcomes over the long term.

\section{Blood Pressure Control}

Of the 50 identified studies that reported blood pressure control, 47 were randomized, controlled trials. These studies had substantial protocol differences, including maximal medication dose, whether additional blood pressure medications were permitted, whether adjustments were by algorithm or physician discretion, whether nonresponders were withdrawn, and whether blood pressure was reported as a change or only as final blood pressure. Thirty-seven studies ( 42 articles) reported no statistically significant differences in blood pressure control (27-68), 2 studies (3 articles) favored ACE inhibitors (69-71), 8 studies favored ARBs (72-79), and 3 studies did not report the comparison between the agents $(80-82)$. Both studies favoring ACE inhibitors compared $50 \mathrm{mg}$ of losartan with $20 \mathrm{mg}$ of enalapril, in contrast to other studies showing no difference between these 2 agents, which compared $100 \mathrm{mg}$ of losartan with 10 or $20 \mathrm{mg}$ of enalapril. For studies that favored $A R B s$, we found no salient features of the study design that might explain the difference. Notably, across studies, the modal difference in systolic or diastolic blood pressure was $0 \mathrm{~mm} \mathrm{Hg}$ and generally did not exceed $4 \mathrm{~mm} \mathrm{Hg}$.

\section{Success as a Single Antihypertensive Agent}

We identified 22 studies $(27,34,37,42-44,46,47$, $49,53,55,58-60,66-69,73,80,82,83)$ that reported successful monotherapy. The definition of "successful" differed across studies. Definitions included various systolic or diastolic blood pressure cutoffs or lack of additional antihypertensive medication at the end of the study. The rates of successful monotherapy ranged between $6 \%$ and $93 \%$ (median, 61\%). The average proportion of patients who achieved successful monotherapy across all studies was about 55\% for both ACE inhibitors and ARBs.

Figure 2 shows estimates for the differences between ACE inhibitors and ARBs in the proportion of patients achieving successful blood pressure control with a single agent. We found no important statistical heterogeneity for these estimates $\left(Q\right.$ statistic $\left.=25.8 ; I^{2}=18 \% ; P=0.22\right)$. The summary estimate using a random-effects model was $1.3 \%$ (95\% CI, $-1.0 \%$ to $3.5 \%$; $P=0.26$ ). Results based on odds ratios and median incidence were similar.

Because the definition of successful control of blood pressure with a single agent requires that a patient continue the originally prescribed drug regimen and receive no additional antihypertensive agent, successful monotherapy reflects both the efficacy of the medication and tolerability and adherence to the prescribed therapy. The tendency in favoring ARBs for this outcome seemed driven primarily by differences in tolerability and adherence. The observed benefit of ARBs seemed heavily influenced by retrospective cohort studies, in which medication discontinuation rates were higher in ACE inhibitor-treated patients, and by randomized, controlled trials that had loosely defined protocols for medication titration and switching.

1 January 2008 |Annals of Internal Medicine $\mid$ Volume $148 \cdot$ Number $1 \mid \mathbf{1 9}$ 
Table 2. Summary of Reviewed Studies*

\begin{tabular}{|c|c|c|c|c|c|c|c|}
\hline \multirow[t]{2}{*}{ Outcome } & \multirow[t]{2}{*}{ Study Design } & \multirow{2}{*}{$\begin{array}{l}\text { Studies, } \\
n\end{array}$} & \multicolumn{3}{|c|}{ Study Quality, n } & \multirow{2}{*}{$\begin{array}{l}\text { Participants, } \\
\text { nt }\end{array}$} & \multirow{2}{*}{$\begin{array}{l}\text { Publication } \\
\text { Years }\end{array}$} \\
\hline & & & Good & Fair & Poor & & \\
\hline \multirow[t]{4}{*}{ Blood pressure control } & $\mathrm{RCT}$ & 47 & 5 & 31 & 11 & 12295 & 1995-2006 \\
\hline & Non-RCT & 1 & 0 & 0 & 1 & 62 & 2000 \\
\hline & Retrospective cohort & 1 & 0 & 1 & 0 & 1087 & 2002 \\
\hline & Case-control & 1 & 0 & 0 & 1 & 88 & 2000 \\
\hline Death and major cardiovascular events & $\mathrm{RCT}$ & 9 & 3 & 5 & 1 & 3322 & 2000-2006 \\
\hline Quality of life & $\mathrm{RCT}$ & 4 & 0 & 4 & 0 & 1142 & 1999-2002 \\
\hline \multirow[t]{3}{*}{ Rate of use of a single antihypertensive } & $\mathrm{RCT}$ & 19 & 3 & 13 & 3 & 4851 & 1995-2005 \\
\hline & Retrospective cohort & 2 & 0 & 2 & 0 & 7071 & 2002-2005 \\
\hline & Case-control & 1 & 0 & 0 & 1 & 88 & 2000 \\
\hline \multirow[t]{2}{*}{ Lipid levels } & $\mathrm{RCT}$ & 11 & 2 & 7 & 2 & 1613 & 1995-2005 \\
\hline & Case-control & 1 & 0 & 0 & 1 & 88 & 2000 \\
\hline Progression to type 2 diabetes & - & - & - & - & - & - & - \\
\hline \multirow[t]{3}{*}{ Markers of carbohydrate metabolism or diabetes control } & $\mathrm{RCT}$ & 11 & 2 & 7 & 2 & 1614 & 1995-2005 \\
\hline & Non-RCT & 1 & 0 & 0 & 1 & 62 & 2000 \\
\hline & Case-control & 1 & 0 & 0 & 1 & 88 & 2000 \\
\hline \multirow[t]{3}{*}{ Measures of left ventricular mass or function } & $\mathrm{RCT}$ & 6 & 0 & 3 & 3 & 566 & 2002-2005 \\
\hline & Non-RCT & 1 & 0 & 0 & 1 & 62 & 2000 \\
\hline & Case-control & 1 & 0 & 0 & 1 & 88 & 2000 \\
\hline \multirow{4}{*}{$\begin{array}{l}\text { Measures of kidney disease (creatinine level, glomerular filtration } \\
\text { rate, proteinuria) }\end{array}$} & $\mathrm{RCT}$ & 16 & 2 & 11 & 3 & 2574 & 1995-2005 \\
\hline & Non-RCT & 1 & 0 & 0 & 1 & 62 & 2000 \\
\hline & Cross-sectional cohort & 1 & 0 & 0 & 1 & 49 & 2003 \\
\hline & Case-control & 1 & 0 & 0 & 1 & 88 & 2000 \\
\hline Serious adverse events (overall rates) & RCT & 7 & 1 & 6 & 0 & 3829 & 1997-2006 \\
\hline Adverse events (overall rates) & $\mathrm{RCT}$ & 29 & 4 & 20 & 5 & 10482 & 1995-2006 \\
\hline \multirow[t]{3}{*}{ Cough } & $\mathrm{RCT}$ & 26 & 4 & 20 & 2 & 10070 & 1995-2006 \\
\hline & Prospective cohort & 2 & 0 & 0 & 2 & 51859 & 1999-2001 \\
\hline & Cross-sectional cohort & 1 & 0 & 0 & 1 & 49 & 2003 \\
\hline Angioedema & $\mathrm{RCT}$ & 3 & 0 & 3 & 0 & 1209 & 1999-2000 \\
\hline \multirow[t]{3}{*}{ Withdrawals due to adverse events } & $\mathrm{RCT}$ & 22 & 2 & 18 & 2 & 7514 & 1995-2005 \\
\hline & Non-RCT & 1 & 0 & 0 & 1 & 62 & 2000 \\
\hline & Case-control & 1 & 0 & 0 & 1 & 88 & 2000 \\
\hline \multirow[t]{2}{*}{ Adherence or persistence } & RCT & 8 & 0 & 7 & 1 & 3366 & 2000-2006 \\
\hline & Retrospective cohort & 9 & 0 & 8 & 1 & 220106 & 1998-2006 \\
\hline
\end{tabular}

* $\mathrm{ACE}=$ angiotensin-converting enzyme; $\mathrm{ARB}=$ angiotensin II receptor blocker; RCT $=$ randomized, controlled trial.

† Represents number included in ACE inhibitor and ARB treatment groups or, in the case of RCTs, number randomly assigned.

\section{Death and Major Cardiovascular Events}

Only 9 studies, described in 13 publications $(27,29$, $31,38,41,44,46,48,49,59,62,65,79)$, reported how many patients died or had myocardial infarction or stroke (Table 2). Most of these studies excluded patients with clinically significant cardiovascular disease and other comorbid conditions. Of 3322 patients who received an ACE inhibitor or an ARB in these studies, 16 died; 12 of these were from a study by Barnett and colleagues (29). That study provided the most and the longest-term data on cardiovascular events, evaluating telmisartan $(n=120)$ versus enalapril $(n=130)$ in patients with type 2 diabetes and early nephropathy over a 5-year treatment period. Event rates were similar in this higher-risk sample, with stroke, congestive heart failure, nonfatal myocardial infarction, or death occurring in 31 patients receiving telmisartan (25.8\% [CI, $18.3 \%$ to $34.6 \%])$ and 25 patients receiving enalapril (19.2\% [CI, $12.9 \%$ to $27.1 \%])$. In none of the studies did investigators attribute any observed events directly to therapy.

$20 \mid 1$ January 2008 $\mid$ Annals of Internal Medicine $\mid$ Volume $148 \bullet$ Number 1

\section{Lipid Levels and Glucose Control}

Eleven randomized, controlled trials $(36,38-40,42$, $44,46,58,62,67,70)$ and 1 observational case-control study (68) reported lipid levels. We rated most of these studies as fair quality. None addressed the use of lipidlowering agents during the study. Nine studies found no change either between or within groups in total cholesterol, low-density lipoprotein, high-density lipoprotein, or triglyceride levels during the study. The remaining 3 studies detected a small but statistically significant change within the groups in total cholesterol $(44,46)$, low-density lipoprotein (36), and triglyceride levels (44). The magnitude of these changes was equivalent for the compared medications except for 1 of the total cholesterol studies (44), which favored the ARB, and the low-density lipoprotein study (36), which favored the ACE inhibitor.

Thirteen studies measured glucose or hemoglobin $A_{1 c}$. All but $2(28,68)$ were randomized, controlled trials. We rated 2 as good quality $(36,62), 7$ as fair quality $(38-40$, $46,53,67,70)$, and 4 as poor quality $(28,42,44,68)$. 
None addressed hypoglycemic therapy during the study. No change occurred in hemoglobin $A_{1 c}$ either between or within groups in 11 studies. One reported a small decrease in glucose that was statistically greater in the ACE inhibitor group (36), and 1 reported a statistically significant but clinically unimportant increase in hemoglobin $A_{1 c}$ for both groups (46). Results were similar between the 6 studies that specifically included diabetic patients and the studies that did not.

\section{Left Ventricular Mass or Function}

Eight studies presented results on left ventricular mass or function assessed by left ventricular mass index $(28,35$, $68)$, left ventricular ejection fraction $(32,61)$, or both $(34$, $57,65)$. Half of these studies had fewer than 50 patients $(28,35,61,65)$, whereas the other half had 100 or more patients $(32,34,57,68)$. All but $2(28,68)$ were randomized, controlled trials. Two had relatively long-term fol- low-up ( $\geq 3$ years) $(35,68), 5$ had between 6 and 12 months of follow-up $(28,32,34,57,65)$, and 1 had only 3 months of follow-up (61). Despite differences in sample size, study design, length of follow-up, study quality, therapeutic agents, and outcome measure, most of the studies demonstrated either similar differences in improvements in left ventricular mass or function, with an approximately $2 \%$ difference between the ACE inhibitor and ARB groups $(28,34,65,68)$, or no change in these measures for either group $(35,57)$.

\section{Serum Creatinine Level, Glomerular Filtration Rate, and Proteinuria}

Twenty studies identified renal outcomes. We excluded 1 of these studies (65) from our analysis because no changes would be expected in the outcome assessed (serum creatinine) in the sample studied (patients with end-stage renal disease who had been receiving maintenance hemo-

\section{Figure 2. Successful monotherapy: angiotensin-converting enzyme (ACE) inhibitors versus angiotensin II receptor blockers (ARBs).}

\begin{tabular}{|c|c|c|c|}
\hline \multirow[t]{2}{*}{ Study, Year (Reference) } & \multirow[t]{2}{*}{ Time Point, $w k$} & \multicolumn{2}{|c|}{ Events/Total, $n / n$} \\
\hline & & ARB & ACE Inhibitor \\
\hline Verdecchia et al., 2000 (68) & 172 & $12 / 22$ & $32 / 66$ \\
\hline Mazzaglia et al., 2005 (83) & 52 & $348 / 1382$ & $1072 / 4602$ \\
\hline Hasford et al., 2002 (80) & 52 & $394 / 754$ & $140 / 333$ \\
\hline \multicolumn{4}{|l|}{ Fixed } \\
\hline \multicolumn{4}{|l|}{ Random } \\
\hline Saito et al., 2004 (60) & 26 & $66 / 200$ & $51 / 214$ \\
\hline Cuspidi et al., 2002 (34) & 48 & $53 / 115$ & $57 / 124$ \\
\hline Ruilope et al., 2001 (59) & 12 & $153 / 168$ & $152 / 163$ \\
\hline Larochelle et al., 1997 (47) & 12 & $11 / 121$ & $4 / 61$ \\
\hline Lacourcière et al., 2000 (46) & 52 & $20 / 52$ & $30 / 51$ \\
\hline Ruff et al., 1996 (69) & 12 & $3 / 50$ & $4 / 25$ \\
\hline Townsend et al., 1995 (66) & 12 & $62 / 132$ & $72 / 136$ \\
\hline Neutel et al., 1999 (55) & 48 & $169 / 385$ & $93 / 193$ \\
\hline Karlberg et al., 1999 (43) & 26 & $89 / 139$ & $88 / 139$ \\
\hline Malacco et al., 2004 (49) & 16 & $479 / 604$ & $479 / 609$ \\
\hline Fogari et al., 2004 (73) & 16 & $45 / 75$ & $39 / 75$ \\
\hline Rosei et al., 2005 (58) & 24 & $39 / 66$ & $40 / 63$ \\
\hline Ghiadoni et al., 2003 (42) & 26 & $23 / 29$ & $21 / 28$ \\
\hline Uchiyama-Tanaka et al., 2005 (67) & 52 & $14 / 18$ & $19 / 25$ \\
\hline Argenziano and Trimarco, 1999 (27) & 26 & $182 / 264$ & $182 / 264$ \\
\hline Robles et al., 2004 (82) & 12 & $10 / 15$ & $11 / 15$ \\
\hline Kavgaci et al., 2002 (44) & 26 & $13 / 20$ & $7 / 10$ \\
\hline Mogensen et al., 2000 (53) & 24 & $54 / 66$ & $46 / 64$ \\
\hline Eguchi et al., 2003 (37) & 12 & $29 / 37$ & $29 / 36$ \\
\hline \multicolumn{4}{|l|}{ Fixed } \\
\hline Random & & & \\
\hline
\end{tabular}

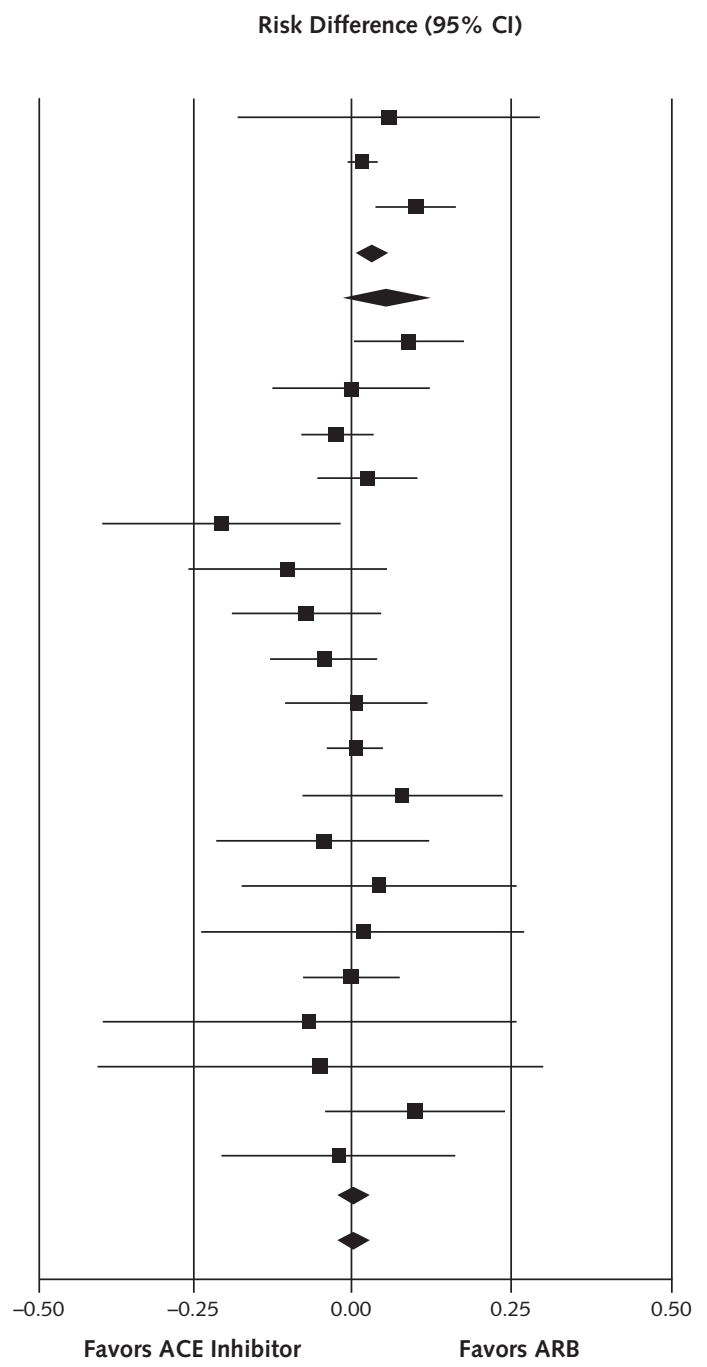

The first group is observational studies and the second group is randomized, controlled trials. 
dialysis for $\geq 1$ month). Of the remaining 19 studies, 9 assessed either serum creatinine or glomerular filtration rate $(28,35,38,39,52,63,67,68,78), 4$ assessed proteinuria $(36,53,62,84)$, and 6 assessed both $(29,44,46,50,58,70)$.

The 15 studies that described changes in creatinine level or glomerular filtration rate did not consistently demonstrate differential effects related to renal function with the use of ACE inhibitors versus ARBs. Among the 9 studies that reported data on renal function, none was rated as good quality, 4 were of poor quality $(28,44,63,68), 2$ were not randomized, controlled trials $(28,68)$, and only 2 had more than 100 patients $(29,52)$. All but $2(29,52)$ compared losartan with a specific ACE inhibitor. The most frequently studied ACE inhibitor was enalapril (28, 29, 35, 63, 68). The 10 studies that described changes in urine albumin level or protein excretion consistently were of fair quality and demonstrated no differential effects between ACE inhibitors and ARBs related to the reduction of urinary protein or albumin excretion among patients with essential hypertension.

\section{Quality of Life, Adverse Events, Persistence, and Adherence}

On the basis of 4 studies, 2 of which did not provide quantitative data, we found no differences in measures of general quality of life. Angiotensin-converting enzyme inhibitors have been consistently shown to be associated with a greater risk for cough than ARBs (Peto pooled odds ratio, 0.32 ). For randomized, controlled trials, this translates to a difference in rates of cough of $6.7 \%$; however, for cohort studies with lower rates of cough, this translates to a difference of $1.1 \%$. We found no evidence of differences in rates of other commonly reported specific adverse events. Angioedema was reported only in patients treated with ACE inhibitors; however, because angioedema was rarely explicitly reported in the included studies, we could not estimate its frequency in this population. Pill counts indicated that rates of adherence to ACE inhibitors and ARBs were similar; this result may not be applicable outside the clinical trial setting. Rates of continuation with therapy seem to be somewhat better with ARBs than with ACE inhibitors; however, the precise magnitude of this effect is difficult to quantify.

\section{Quality of Life}

Four fair-quality studies described in 8 papers reported quality-of-life outcomes $(27,31,35,38,41,43,48,76)$. They used a variety of quality-of-life scales. None demonstrated a differential effect on quality of life between ACE inhibitors and ARBs.

\section{Serious and Overall Adverse Events}

Seven studies of either fair or good quality $(43,49,52$, $58,74,78,79)$ reported overall rates of serious adverse events. The biggest issues in evaluating these studies were inconsistent reporting and a low rate of serious adverse events $(0 \%$ to $6 \%)$. A potentially salient and serious adverse event, angioedema, was reported in only 3 of the 61 included studies $(43,51,55)$. All reported cases occurred in patients treated with an ACE inhibitor. Because angioedema was rarely explicitly reported in the included studies, we could not estimate its frequency.

Of the 29 studies that reported overall adverse event rates $(29,30,33,34,36-38,43,45,47,49,51,52,55$, $58,59,63,66,69,70,72-79,81), 20$ were assessed as being fair quality and 5 as poor quality. The manner in which adverse events were reported substantially varied. Depending on the definition used, adverse event rates ranged from $0 \%$ to $100 \%$ (median, 32\%) for ACE inhibitors and $0 \%$ to $96 \%$ (median, 28\%) for ARBs.

\section{Specific Adverse Events}

Thirty studies reported rates of 1 or more specific adverse events $(30,33-36,38,43,45-47,49,51,52,54,55$, $59,66,69,70,72-79,84-86$ ), including cough (29 studies); headache (21 studies); dizziness (18 studies); fatigue (10 studies); upper respiratory infection (6 studies); nausea (6 studies); viral infection, ankle edema, and back pain (3 studies each); and palpitations, myalgia, diarrhea, malaise, and hypotension (2 studies each). Several other adverse events were reported in 1 study, including pharyngitis, rhinitis, dyspnea, abdominal pain, urinary tract infection, constipation, dry mouth, feeling sick, pyrosis, insomnia, musculoskeletal pain, flatulence, epigastric discomfort, increased sweating, and erythematous rash.

Given the large number of commonly reported specific adverse events, we focused on 3 that had the largest difference in absolute rates across studies: headache, dizziness, and cough.

Headache. Twenty-one studies compared headache in patients treated with ACE inhibitors and ARBs. Rates of headache ranged from $1 \%$ to $22 \%$ for ARB-treated groups (overall rate, 6.3\%) and from $0 \%$ to $34 \%$ in ACE inhibitor-treated groups (overall rate, $7.9 \%$ ). Meta-analyses did not reveal evidence of a differential effect of ACE inhibitors and ARBs on headache.

Dizziness. Eighteen studies compared dizziness in patients treated with ACE inhibitors and ARBs. Rates of dizziness ranged from $1 \%$ to $20 \%$ for ARB-treated groups (overall rate, $4.3 \%$ ) and from $0 \%$ to $18 \%$ in ACE inhibitor-treated groups (overall rate, 5.4\%). Meta-analyses did not reveal evidence of a differential effect of ACE inhibitors and ARBs on dizziness.

Cough. Twenty-nine studies compared cough in patients treated with ACE inhibitors and ARBs (30, 33-36, $38,43,45-47,49,51,52,54,55,59,66,69,70,72-74$, $76-79,84-86)$. We rated 4 of these studies as good, 20 as fair, and 5 as poor in quality. Rates of cough ranged from $0 \%$ to $13 \%$ for ARB-treated groups (mean, $3 \%$; median, $1 \%$ ) and from $0 \%$ to $23 \%$ in ACE inhibitor-treated groups (mean, 10\%, median, 9\%). All 29 studies demon- 


\section{Figure 3. Cough as an adverse event: angiotensin-converting enzyme (ACE) inhibitors versus angiotensin II receptor blockers} (ARBs).

\begin{tabular}{|c|c|c|}
\hline \multirow[t]{2}{*}{ Study, Year (Reference) } & \multicolumn{2}{|c|}{ Events/Total, $n / n$} \\
\hline & ARB & ACE Inhibitor \\
\hline Sato et al., 2003 (84) & $0 / 26$ & $2 / 23$ \\
\hline Grégoire et al., 2001 (85) & $4 / 80$ & $55 / 369$ \\
\hline Mackay et al., 1999 (86) & $64 / 14522$ & $566 / 36888$ \\
\hline \multicolumn{3}{|l|}{ Fixed } \\
\hline \multicolumn{3}{|l|}{ Random } \\
\hline Cuspidi et al., 2002 (34) & $3 / 115$ & $11 / 124$ \\
\hline Malmqvist et al., 2000 (76) & $0 / 140$ & $19 / 146$ \\
\hline Mclnnes et al., 2000 (51) & $11 / 237$ & $27 / 116$ \\
\hline Derosa et al., 2003 (36) & $0 / 47$ & $2 / 49$ \\
\hline Elliott, 1999 (38) & $34 / 264$ & $59 / 264$ \\
\hline Ruilope et al., 2001 (59) & $1 / 168$ & $10 / 163$ \\
\hline Koylan et al., 2005 (45) & $3 / 337$ & $28 / 298$ \\
\hline Coca et al., 2002 (33) & $1 / 111$ & $10 / 115$ \\
\hline Larochelle et al., 1997 (47) & $3 / 121$ & $8 / 61$ \\
\hline Mimran et al., 1998 (52) & $7 / 98$ & $15 / 102$ \\
\hline Roca-Cusachs et al., 1997 (78) & $12 / 192$ & $14 / 204$ \\
\hline De Rosa et al., 2002 (35) & $1 / 26$ & $3 / 24$ \\
\hline Lacourcière et al., 2000 (46) & $0 / 52$ & $7 / 51$ \\
\hline Ruff et al., 1996 (69) & $4 / 50$ & $3 / 25$ \\
\hline Tikkanen et al., 1995 (70) & $2 / 202$ & $25 / 205$ \\
\hline Townsend et al., 1995 (66) & $2 / 132$ & $8 / 136$ \\
\hline Neutel et al., 1999 (55) & $12 / 385$ & $14 / 193$ \\
\hline Amerena et al., 2002 (72) & $2 / 264$ & $23 / 258$ \\
\hline Karlberg et al., 1999 (43) & 9/139 & $22 / 139$ \\
\hline Lacourcière et al., 2006 (74) & $1 / 405$ & $33 / 407$ \\
\hline Williams et al., 2006 (79) & $2 / 397$ & $23 / 404$ \\
\hline Ragot et al., 2002 (77) & $2 / 220$ & $12 / 221$ \\
\hline Black et al., 1997 (30) & $4 / 364$ & $15 / 187$ \\
\hline Malacco et al., 2004 (49) & $6 / 604$ & $44 / 609$ \\
\hline Fogari et al., 2004 (73) & $1 / 75$ & $4 / 75$ \\
\hline Naidoo et al., 1999 (54) & $12 / 176$ & 29/173 \\
\hline Fixed & & \\
\hline Random & & \\
\hline
\end{tabular}

Peto Odds Ratio $(95 \% \mathrm{Cl})$

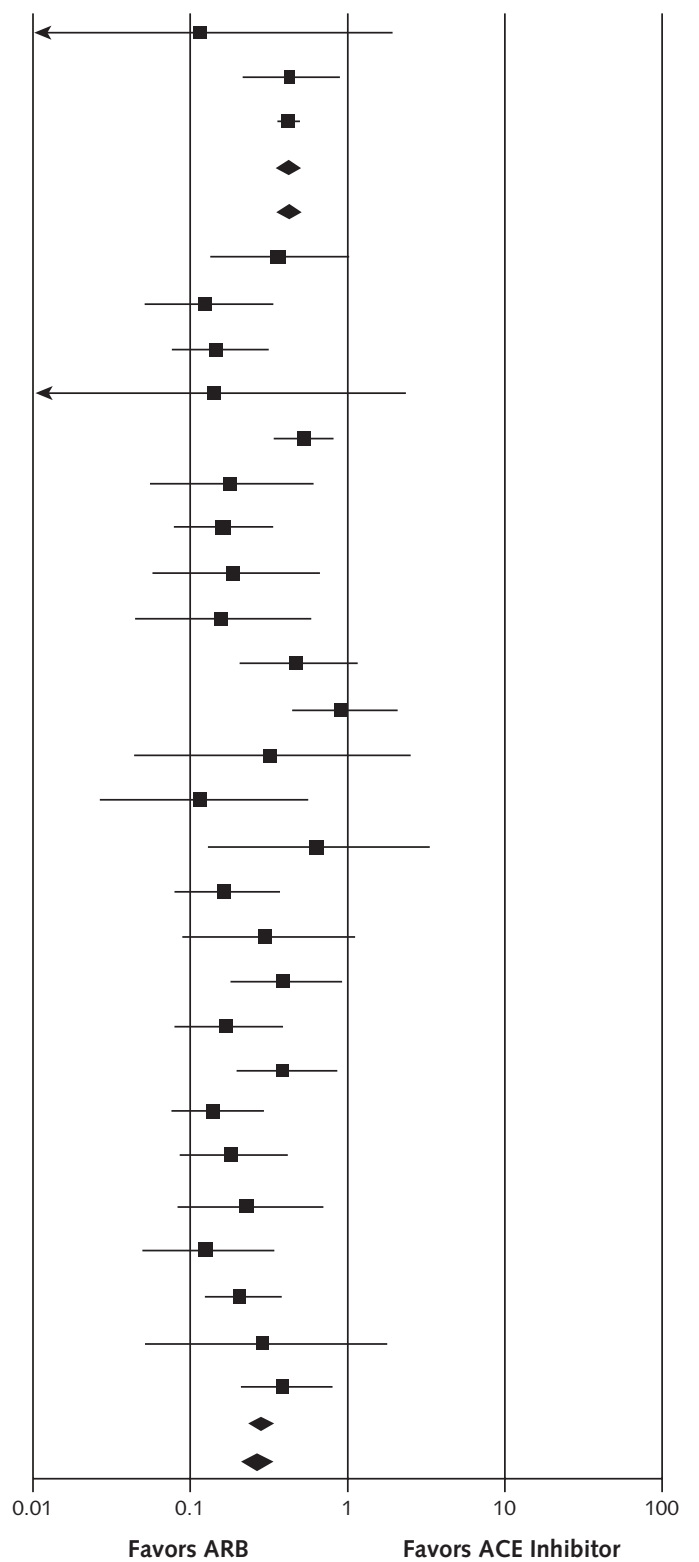

The first group is observational studies and the second group is randomized, controlled trials.

strated higher rates of cough in ACE inhibitor-treated participants. For the meta-analysis of studies reporting cough as an adverse event, we included all 29 studies that reported cough rates (Figure 3). The Cochran $Q$ test and the $I^{2}$ between studies demonstrated statistical heterogeneity among the studies $\left(Q\right.$ statistic $\left.=57.5 ; I^{2}=51.3 \%\right)$. The observed rates of cough were much higher in randomized, controlled trials, in which patients were queried systematically for the symptom, than those in cohort studies. The rates of cough in randomized, controlled trials were $9.9 \%$ for the ACE inhibitor group and $3.2 \%$ for the ARB group (absolute risk difference, 6.7 percentage points), whereas the rates of cough in cohort studies were $1.7 \%$ for the ACE inhibitor group and $0.6 \%$ for the ARB group (absolute risk difference, 1.1 percentage points).

\section{Withdrawals Due to Adverse Events}

Twenty-four studies $(28-30,33-35,38,43,45,46$, $49,51-55,62,63,66,68,70,72,75,78)$ reported with- 


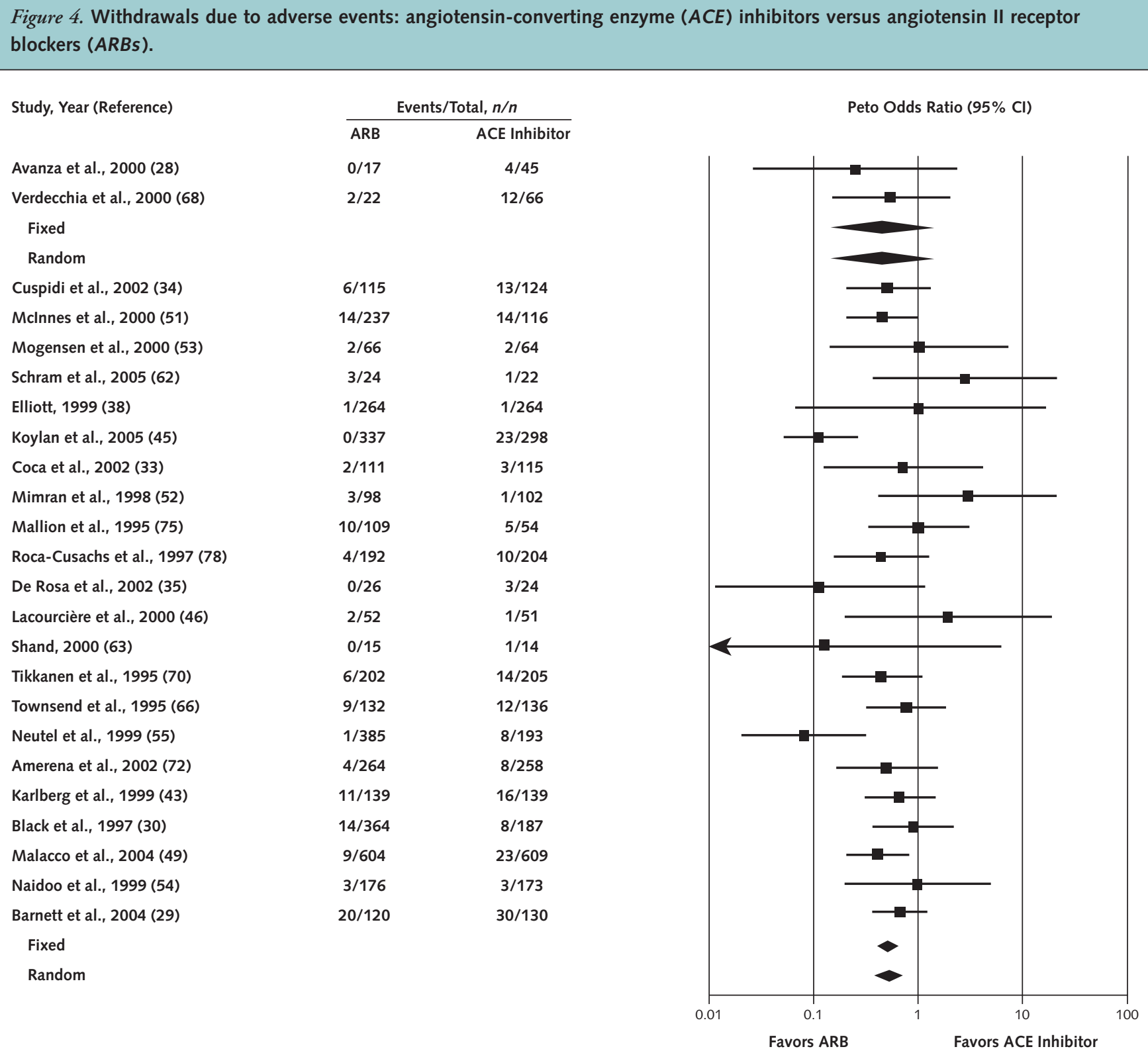

The first group is observational studies and the second group is randomized, controlled trials.

drawals due to adverse events. We rated 2 as good in methodological quality, 18 as fair, and 4 as poor. Rates of withdrawal due to adverse events ranged from $1 \%$ to $41 \%$ (mean, 10\%; median, 3\%) for patients who received ARBs and $1 \%$ to $41 \%$ (mean, $19 \%$; median, $8 \%$ ) for patients who received ACE inhibitors. Sixteen studies demonstrated higher withdrawal rates in ACE inhibitor-treated participants, 3 demonstrated higher rates in ARB-treated participants, and 5 showed no difference in rates (Figure 4). The differences in rates of adverse events (such as cough) and the duration of the trials probably explain this heterogeneity. We found modest statistical heterogeneity between studies $(Q$ statistic $=$ $\left.36.0 ; I^{2}=36.2 \%\right)$. The Peto summary odds ratio fa- vored $\mathrm{ARBs}$ (0.51 [CI, 0.38 to 0.70$]$; random-effects model). Given this odds ratio and a median withdrawal rate of $8 \%$ for ACE inhibitors, the expected withdrawal rate for $A R B s$ is $3.7 \%$.

Caveats regarding these data are that only 1 study was of good methodological quality and reporting of withdrawal data varied greatly.

\section{Adherence and Persistence}

Seventeen studies described in 19 papers $(33,45,51$, $58,60,72,76,79,80,83,87-95)$ reported quantitative information on persistence or adherence. We operationally defined adherence as the consistency with which medica- 
tion was taken, measured by such direct evidence as pill counts. Collecting such evidence typically requires an experimental setting; this limits the ability to generalize because patients who participate in trials and are aware that they are being observed will probably demonstrate better adherence than those in usual practice. Adherence for both ACE inhibitors and ARBs was high (>90\%).

We operationally defined persistence as the percentage of patients continuing a particular therapy after a certain period (for example, patients continuing ARB therapy 12 months after the initial prescription), where the patient's treatment status was determined by the pattern of filled prescriptions. Thus, persistence could be measured in nonexperimental settings (for example, by using administrative databases).

Studies addressing persistence included 2 randomized, controlled trials and 9 longitudinal cohort studies. These studies consistently showed that persistence with ARBs was somewhat better than persistence with ACE inhibitors (Table 3); for example, the median absolute difference in persistence rates for the longitudinal cohort studies was in the range of $6 \%$ to $7 \%$.

Certain caveats apply to these results. The longitudinal cohort studies typically used administrative databases. Although investigators in these studies often presented analyses that statistically controlled for differences in characteristics between patients receiving ACE inhibitors and those receiving $A R B s$, the absence of randomization means that similarity in unmeasured patient characteristics within the groups cannot be guaranteed. Consequently, the consis- tency of results reported in Table 3 (across experimental vs. nonexperimental studies, among the various longitudinal cohort studies, and over time within a study) is crucial. In addition, several longitudinal cohort studies, such as those by Marentette and colleagues (93), Bourgault and colleagues (88), Burke and colleagues (95), Wogen and colleagues (94), and Degli Esposti and colleagues $(90,91)$, corresponded in time to the introduction of $\mathrm{ARBs}$ and thus have relatively small sample sizes for this medication class. Persistence estimates are less precise in these studies than might be desired.

\section{Effects in Subgroups of Patients}

We found inadequate evidence regarding comparative effectiveness, adverse events, or tolerability of ACE inhibitors and ARBs for any particular patient subgroup (6).

\section{DISCUSSION}

With the exception of rates of cough, the available evidence does not strongly support the hypothesis that ACE inhibitors and ARBs have clinically meaningful differences in benefits or harms for individuals with essential hypertension. In particular, both classes of therapy provide similar levels of blood pressure control and seem to have an equivalent effect on death and cardiovascular events; major adverse events; quality of life; and risk factors, such as lipid levels, diabetes mellitus, and left ventricular mass and function. Evidence suggests that ARBs are associated with higher rates of persistence with initial therapy than are

\section{Table 3. Studies of Persistence*}

Study

Randomized trials

Saito et al., 2004 (60)

Koylan et al., 2005 (45)

Longitudinal cohort studies

Hasford et al., 2002 (80)

Mazzaglia et al., 2005 (83)

Bloom, 1998 (87)†

Conlin et al., 2001 (89) $\dagger$

Erkens et al., 2005 (92)

Marentette et al., 2002 (93)

Bourgault et al., 2005 (88)

Burke et al., 2006 (95)

Wogen et al., 2003 (94)

Degli Esposti et al., $2002(90,91)$

\section{Duration of Therapy}

ACE Inhibitors, \%

\begin{tabular}{|c|c|c|c|c|c|c|}
\hline & & & & & & \\
\hline & Continued & Switched & Discontinued & Continued & Switched & Discontinued \\
\hline $6 \mathrm{mo}$ & 71 & 28 & 2 & 89 & 9 & 2 \\
\hline $6 \mathrm{mo}$ & $\approx 82$ & - & - & $\approx 89$ & - & - \\
\hline
\end{tabular}

* The ideal outcome would disaggregate patients into 4 mutually exclusive and exhaustive categories: continued initial medication without change, continued initial

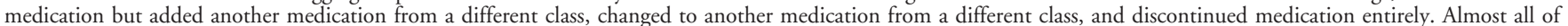

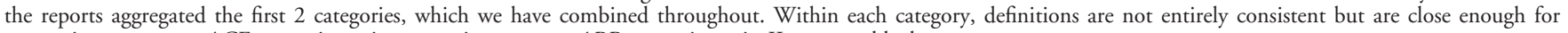
comparison purposes. $\mathrm{ACE}=$ angiotensin-converting enzyme; $\mathrm{ARB}=$ angiotensin II receptor blocker.

+ These studies are from the same research team and report on the same study population at 1 year (Bloom) and 4 years (Conlin et al.). 
ACE inhibitors, although the magnitude of this difference is difficult to quantify.

The literature had important limitations. Assessment of the long-term effect of treatment is restricted by the dearth of truly long-term studies; follow-up exceeded 6 months in only one third of head-to-head studies. Many of the studies reported limited data on patient characteristics, did not report results by subpopulation, and underrepresented black patients. Study protocols had substantial differences, including maximal medication dose, whether additional blood pressure medications were permitted, whether adjustments were by algorithm or physician discretion, and whether nonresponders were withdrawn at some point in the study.

Assessment of outcomes was not uniform. Blood pressure was reported in some studies only as final blood pressure and in other studies as change in blood pressure. Important outcomes, such as death, vascular events, and angioedema, were often not mentioned.

This review highlights several issues that should be addressed by further research. In addition to examining the effect of therapy over several years, studies should incorporate pragmatic designs, such as clinical trials in which treatment is consistent with typical clinical practice, or randomization by organizationally meaningful clusters, such as practice organizations or health plans. Assessments should consider subgroups of special importance, such as individuals with essential hypertension and diabetes mellitus, congestive heart failure, chronic kidney disease, and dyslipidemia, and should have broader representation of such groups as elderly persons and ethnic and racial minorities. Given the demonstrated higher incidence of cough with ACE inhibitors, it would also be valuable to gain a more precise understanding of the effect of cough on quality of life, care patterns (for example, use of therapeutic agents for cough symptoms or conditions associated with cough), and health outcomes, particularly for individuals who continue to use ACE inhibitors.

Although a strong clinical motivation exists to differentiate among therapies to achieve optimal outcomes and to tailor treatment to the individual patient, this review indicates that, for the relatively low-risk individual with essential hypertension, any differences between ACE inhibitors and ARBs in major events or changes in risk factors are likely to be small. Identifying such small differences is a substantial challenge requiring large, prolonged studies in generalizable populations and settings. However, in the face of the considerable effect of marginal differences in treatment efficacy for common conditions, such an effort may well be justified.

From Duke Center for Clinical Health Policy Research, Duke Clinical Research Institute, Duke University, and the Center for Health Services Research in Primary Care, Durham U.S. Department of Veterans Affairs Medical Center, Durham, North Carolina.
Disclaimer: The authors of this report are responsible for its content. Statements in the report should not be construed as endorsements by the Agency for Healthcare Research and Quality or the U.S. Department of Health and Human Services.

Grant Support: This project was funded under contract no. 290-020025 from the Agency for Healthcare Research and Quality, U.S. Department of Health and Human Services.

Potential Financial Conflicts of Interest: Honoraria: D.C. McCrory (AstraZeneca). Stock ownership or options (other than mutual funds): G.P. Samsa (Pfizer).

Requests for Single Reprints: David B. Matchar, MD, Duke Center for Clinical Health Policy Research, 2200 West Main Street, Suite 220, Durham, NC 27705; e-mail, david.matchar@duke.edu.

Current author addresses are available at www.annals.org.

\section{References}

1. World Health Organization. World health report 2002: reducing risks, promoting healthy life. Geneva: World Health Organization; 2002. Accessed at www.who.int/whr/2002 on 14 December 2006.

2. Chobanian AV, Bakris GL, Black HR, Cushman WC, Green LA, Izzo JL Jr, et al.; National Heart, Lung, and Blood Institute Joint National Committee on Prevention, Detection, Evaluation, and Treatment of High Blood Pressure. The Seventh Report of the Joint National Committee on Prevention, Detection, Evaluation, and Treatment of High Blood Pressure: the JNC 7 report. JAMA. 2003;289:2560-72. [PMID: 12748199]

3. Israili ZH, Hall WD. Cough and angioneurotic edema associated with angiotensin-converting enzyme inhibitor therapy. A review of the literature and pathophysiology. Ann Intern Med. 1992;117:234-42. [PMID: 1616218]

4. Chou R, Helfand M, Carson S. Drug Class Review on Angiotensin Converting Enzyme Inhibitors. Final Report. Portland, OR: Oregon Health \& Science Univ; 2005. Accessed at www.ohsu.edu/drugeffectiveness/reports/final.cfm on 17 August 2006.

5. Furmaga E, Glassman P, Rhodes S, Suttorp M, Mojica W. Drug Class Review on Angiotensin II Receptor Antagonists. Final Report. Portland, OR: Oregon Health \& Science Univ; 2006. Accessed at www.ohsu.edu/drugeffectiveness/reports/final.cfm on 17 August 2006.

6. Matchar DB, McCrory DC, Orlando LA, Patel MR, Patel UD, Patwardhan $\mathrm{MB}$, et al. Comparative Effectiveness of Angiotensin-Converting Enzyme Inhibitors (ACEIs) and Angiotensin II Receptor Antagonists (ARBs) for Treating Essential Hypertension. Comparative Effectiveness Review No. 10. (Prepared by Duke Evidence-based Practice Center under Contract No. 290-02-0025.) Rockville, MD: Agency for Healthcare Research and Quality; November 2007. Available at: www.effectivehealthcare.ahrq.gov/reports/final.cfm.

7. Anan F, Takahashi N, Ooie T, Yufu K, Hara M, Nakagawa M, et al. Effects of valsartan and perindopril combination therapy on left ventricular hypertrophy and aortic arterial stiffness in patients with essential hypertension. Eur J Clin Pharmacol. 2005;61:353-9. [PMID: 15918057]

8. Andersen NH, Poulsen SH, Poulsen PL, Knudsen ST, Helleberg K, Hansen $\mathrm{KW}$, et al. Effects of blood pressure lowering and metabolic control on systolic left ventricular function in type II diabetes mellitus. Clin Sci (Lond). 2006;111: 53-9. [PMID: 16512787]

9. Fogari R, Mugellini A, Zoppi A, Lazzari P, Destro M, Rinaldi A, et al. Effect of telmisartan/hydrochlorothiazide vs lisinopril/hydrochlorothiazide combination on ambulatory blood pressure and cognitive function in elderly hypertensive patients. J Hum Hypertens. 2006;20:177-85. [PMID: 16306998]

10. Hosohata K, Saito S, Asayama K, Ohkubo T, Kikuya M, Metoki H, et al. Progress report on The Hypertension Objective Treatment Based on Measurement by Electrical Devices of Blood Pressure (HOMED-BP) study: status at February 2004. Clin Exp Hypertens. 2007;29:69-81. [PMID: 17190733]

11. Kyvelou SM, Vyssoulis GP, Karpanou EA, Adamopoulos DN, Zervoudaki AI, Pietri PG, et al. Effects of antihypertensive treatment with angiotensin II receptor blockers on lipid profile: an open multi-drug comparison trial. Hellenic J Cardiol. 2006;47:21-8. [PMID: 16532712]

12. Mochizuki S, Dahlof B, Shimizu M, Ikewaki K, Yoshikawa M, Taniguchi 
I, et al.; Jikei Heart Study Group. Valsartan in a Japanese population with hypertension and other cardiovascular disease (Jikei Heart Study): a randomised, open-label, blinded endpoint morbidity-mortality study. Lancet. 2007;369: 1431-9. [PMID: 17467513]

13. Ogawa S, Takeuchi K, Mori T, Nako K, Tsubono Y, Ito S. Effects of monotherapy of temocapril or candesartan with dose increments or combination therapy with both drugs on the suppression of diabetic nephropathy. Hypertens Res. 2007;30:325-34. [PMID: 17541211]

14. Palma-Gámiz JL, Pêgo M, Contreras EM, Anglada MP, Martínez JO, Esquerra EA, et al.; Iberian Multicenter Imidapril Study on Hypertension. A twelve-week, multicenter, randomized, double-blind, parallel-group, noninferiority trial of the antihypertensive efficacy and tolerability of imidapril and candesartan in adult patients with mild to moderate essential hypertension: the Iberian Multicenter Imidapril Study on Hypertension (IMISH). Clin Ther. 2006;28: 2040-51. [PMID: 17296460]

15. Palma-Gamiz JL, Pêgo M, Marquez E, Pujol M, Olivan J, Alegría E, et al. A multicentre, 12-week study of imidapril and candesartan cilexetil in patients with mild to moderate hypertension using ambulatory blood pressure monitoring. Clin Drug Investig. 2007;27:407-17. [PMID: 17506591]

16. Palmas W, Ma S, Psaty B, Goff DC Jr, Darwin C, Barr RG. Antihypertensive medications and C-reactive protein in the multi-ethnic study of atherosclerosis. Am J Hypertens. 2007;20:233-41. [PMID: 17324732]

17. Rehman A, Ismail SB, Naing L, Roshan TM, Rahman AR. Reduction in arterial stiffness with angiotensin II antagonism and converting enzyme inhibition. A comparative study among Malay hypertensive subjects with a known genetic profile. Am J Hypertens. 2007;20:184-9. [PMID: 17261465]

18. Scaglione R, Argano C, Di Chiara T, Parrinello G, Colomba D, Avellone G, et al. Effect of dual blockade of renin-angiotensin system on TGFbetal and left ventricular structure and function in hypertensive patients. J Hum Hypertens. 2007;21:307-15. [PMID: 17301824]

19. Sengul AM, Altuntas Y, Kürklü A, Aydin L. Beneficial effect of lisinopril plus telmisartan in patients with type 2 diabetes, microalbuminuria and hypertension. Diabetes Res Clin Pract. 2006;71:210-9. [PMID: 16112244]

20. Spoelstra-de Man AM, van Ittersum FJ, Schram MT, Kamp O, van Dijk RA, Ijzerman RG, et al. Aggressive antihypertensive strategies based on hydrochlorothiazide, candesartan or lisinopril decrease left ventricular mass and improve arterial compliance in patients with type II diabetes mellitus and hypertension. J Hum Hypertens. 2006;20:599-611. [PMID: 16673014]

21. Tedesco MA, Natale F, Calabrò R. Effects of monotherapy and combination therapy on blood pressure control and target organ damage: a randomized prospective intervention study in a large population of hypertensive patients. J Clin Hypertens (Greenwich). 2006;8:634-41. [PMID: 16957425]

22. Harris RP, Helfand M, Woolf SH, Lohr KN, Mulrow CD, Teutsch SM, et al.; Methods Work Group, Third US Preventive Services Task Force. Current methods of the US Preventive Services Task Force: a review of the process. Am J Prev Med. 2001;20:21-35. [PMID: 11306229]

23. Undertaking systematic reviews of research on effectiveness: CRD's guidance for those carrying out or commissioning reviews. CRD report no. 4. 2nd ed. York, United Kingdom: NHS Centre for Reviews and Dissemination; 2001.

24. Rothwell PM. External validity of randomised controlled trials: "to whom do the results of this trial apply?”. Lancet. 2005;365:82-93. [PMID: 15639683]

25. Atkins D, Best D, Briss PA, Eccles M, Falck-Ytter Y, Flottorp S, et al.; GRADE Working Group. Grading quality of evidence and strength of recommendations. BMJ. 2004;328:1490. [PMID: 15205295]

26. Bradburn MJ, Deeks JJ, Berlin JA, Localio AR. Much ado about nothing: a comparison of the performance of meta-analytical methods with rare events. Stat Med. 2007;26:53-77. [PMID: 16596572]

27. Argenziano L, Trimarco B. Effect of eprosartan and enalapril in the treatment of elderly hypertensive patients: subgroup analysis of a 26-week, doubleblind, multicentre study. Eprosartan Multinational Study Group. Curr Med Res Opin. 1999;15:9-14. [PMID: 10216806]

28. Avanza AC Jr, El Aouar LM, Mill JG. Reduction in left ventricular hypertrophy in hypertensive patients treated with enalapril, losartan or the combination of enalapril and losartan. Arq Bras Cardiol. 2000;74:103-17. [PMID: 10904284] 29. Barnett AH, Bain SC, Bouter P, Karlberg B, Madsbad S, Jervell J, et al.; Diabetics Exposed to Telmisartan and Enalapril Study Group. Angiotensinreceptor blockade versus converting-enzyme inhibition in type 2 diabetes and nephropathy. N Engl J Med. 2004;351:1952-61. [PMID: 15516696]

30. Black HR, Graff A, Shute D, Stoltz R, Ruff D, Levine J, et al. Valsartan, a new angiotensin II antagonist for the treatment of essential hypertension: efficacy, tolerability and safety compared to an angiotensin-converting enzyme inhibitor, lisinopril. J Hum Hypertens. 1997;11:483-9. [PMID: 9322828]

31. Breeze E, Rake EC, Donoghue MD, Fletcher AE. Comparison of quality of life and cough on eprosartan and enalapril in people with moderate hypertension. J Hum Hypertens. 2001;15:857-62. [PMID: 11773988]

32. Celik T, Iyisoy A, Kursaklioglu H, Yilmaz MI, Kose S, Kilic S, et al. The comparative effects of telmisartan and ramipril on P-wave dispersion in hypertensive patients: a randomized clinical study. Clin Cardiol. 2005;28:298-302. [PMID: 16028466]

33. Coca A, Calvo C, Garcia-Puig J, Gil-Extremera B, Aguilera MT, de la Sierra A, et al.; MAPAVEL Investigators (Monitorizacíon Ambulatoria Presión Arterial APROVEL). A multicenter, randomized, double-blind comparison of the efficacy and safety of irbesartan and enalapril in adults with mild to moderate essential hypertension, as assessed by ambulatory blood pressure monitoring: the MAPAVEL Study (Monitorización Ambulatoria Presión Arterial APROVEL). Clin Ther. 2002;24:126-38. [PMID: 11833827]

34. Cuspidi C, Muiesan ML, Valagussa L, Salvetti M, Di Biagio C, AgabitiRosei E, et al.; CATCH investigators. Comparative effects of candesartan and enalapril on left ventricular hypertrophy in patients with essential hypertension: the candesartan assessment in the treatment of cardiac hypertrophy (CATCH) study. J Hypertens. 2002;20:2293-300. [PMID: 12409969]

35. De Rosa ML, Cardace P, Rossi M, Baiano A, de Cristofaro A. Comparative effects of chronic ACE inhibition and AT1 receptor blocked losartan on cardiac hypertrophy and renal function in hypertensive patients. J Hum Hypertens. 2002;16:133-40. [PMID: 11850771]

36. Derosa G, Cicero AF, Ciccarelli L, Fogari R. A randomized, double-blind, controlled, parallel-group comparison of perindopril and candesartan in hypertensive patients with type 2 diabetes mellitus. Clin Ther. 2003;25:2006-21. [PMID: 12946547]

37. Eguchi K, Kario K, Shimada K. Comparison of candesartan with lisinopril on ambulatory blood pressure and morning surge in patients with systemic hypertension. Am J Cardiol. 2003;92:621-4. [PMID: 12943892]

38. Elliott WJ. Double-blind comparison of eprosartan and enalapril on cough and blood pressure in unselected hypertensive patients. Eprosartan Study Group. J Hum Hypertens. 1999;13:413-7. [PMID: 10408592]

39. Fogari R, Mugellini A, Zoppi A, Corradi L, Preti P, Lazzari P, et al. Losartan and perindopril effects on plasma plasminogen activator inhibitor-1 and fibrinogen in hypertensive type 2 diabetic patients. Am J Hypertens. 2002;15: 316-20. [PMID: 11991216]

40. Fogari R, Zoppi A, Preti P, Fogari E, Malamani G, Mugellini A. Differential effects of ACE-inhibition and angiotensin II antagonism on fibrinolysis and insulin sensitivity in hypertensive postmenopausal women. Am J Hypertens. 2001;14:921-6. [PMID: 11587159]

41. Gavras I, Gavras H. Effects of eprosartan versus enalapril in hypertensive patients on the renin-angiotensin-aldosterone system and safety parameters: results from a 26-week, double-blind, multicentre study. Eprosartan Multinational Study Group. Curr Med Res Opin. 1999;15:15-24. [PMID: 10216807]

42. Ghiadoni L, Magagna A, Versari D, Kardasz I, Huang Y, Taddei S, et al. Different effect of antihypertensive drugs on conduit artery endothelial function. Hypertension. 2003;41:1281-6. [PMID: 12719441]

43. Karlberg BE, Lins LE, Hermansson K. Efficacy and safety of telmisartan, a selective AT1 receptor antagonist, compared with enalapril in elderly patients with primary hypertension. TEES Study Group. J Hypertens. 1999;17:293-302. [PMID: 10067800]

44. Kavgaci H, Sahin A, Onder Ersoz H, Erem C, Ozdemir F. The effects of losartan and fosinopril in hypertensive type 2 diabetic patients. Diabetes Res Clin Pract. 2002;58:19-25. [PMID: 12161053]

45. Koylan N, Acarturk E, Canberk A, Caglar N, Caglar S, Erdine S, et al.; Turkish Irbesartan Study Group. Effect of irbesartan monotherapy compared with ACE inhibitors and calcium-channel blockers on patient compliance in essential hypertension patients: a multicenter, open-labeled, three-armed study. Blood Press Suppl. 2005;1:23-31. [PMID: 16060413]

46. Lacourcière $\mathrm{Y}$, Bélanger $\mathrm{A}$, Godin $\mathrm{C}$, Hallé JP, Ross $\mathrm{S}$, Wright $\mathrm{N}$, et al. Long-term comparison of losartan and enalapril on kidney function in hypertensive type 2 diabetics with early nephropathy. Kidney Int. 2000;58:762-9. [PMID: 10916100]

47. Larochelle P, Flack JM, Marbury TC, Sareli P, Krieger EM, Reeves RA. Effects and tolerability of irbesartan versus enalapril in patients with severe hypertension. Irbesartan Multicenter Investigators. Am J Cardiol. 1997;80:1613-5. [PMID: 9416950] 
48. Levine B. Effect of eprosartan and enalapril in the treatment of black hypertensive patients: subgroup analysis of a 26-week, double-blind, multicentre study. Eprosartan Multinational Study Group. Curr Med Res Opin. 1999;15:25-32. [PMID: 10216808]

49. Malacco E, Santonastaso M, Vari NA, Gargiulo A, Spagnuolo V, Bertocchi F, et al.; Blood Pressure Reduction and Tolerability of Valsartan in Comparison with Lisinopril Study. Comparison of valsartan $160 \mathrm{mg}$ with lisinopril 20 $\mathrm{mg}$, given as monotherapy or in combination with a diuretic, for the treatment of hypertension: the Blood Pressure Reduction and Tolerability of Valsartan in Comparison with Lisinopril (PREVAIL) study. Clin Ther. 2004;26:855-65. [PMID: 15262456]

50. Matsuda H, Hayashi K, Saruta T. Distinct time courses of renal protective action of angiotensin receptor antagonists and ACE inhibitors in chronic renal disease. J Hum Hypertens. 2003;17:271-6. [PMID: 12692572]

51. McInnes GT, O'Kane KP, Istad H, Keinänen-Kiukaanniemi S, Van Mierlo HF. Comparison of the AT1-receptor blocker, candesartan cilexetil, and the ACE inhibitor, lisinopril, in fixed combination with low dose hydrochlorothiazide in hypertensive patients. J Hum Hypertens. 2000;14:263-9. [PMID: 10805052]

52. Mimran A, Ruilope L, Kerwin L, Nys M, Owens D, Kassler-Taub K, et al. A randomised, double-blind comparison of the angiotensin II receptor antagonist, irbesartan, with the full dose range of enalapril for the treatment of mild-tomoderate hypertension. J Hum Hypertens. 1998;12:203-8. [PMID: 9579771] 53. Mogensen CE, Neldam S, Tikkanen I, Oren S, Viskoper R, Watts RW, et al. Randomised controlled trial of dual blockade of renin-angiotensin system in patients with hypertension, microalbuminuria, and non-insulin dependent diabetes: the candesartan and lisinopril microalbuminuria (CALM) study. BMJ. 2000; 321:1440-4. [PMID: 11110735]

54. Naidoo DP, Sareli P, Marin F, Aroca-Martinez G, Maritz FJ, Jardim PC, et al. Increased efficacy and tolerability with losartan plus hydrochlorothiazide in patients with uncontrolled hypertension and therapy-related symptoms receiving two monotherapies. Adv Ther. 1999;16:187-99. [PMID: 10915394]

55. Neutel JM, Frishman WH, Oparil S, Papademitriou V, Guthrie G. Comparison of telmisartan with lisinopril in patients with mild-to-moderate hypertension. Am J Ther. 1999;6:161-6. [PMID: 10423659]

56. Rabbia F, Silke B, Carra R, Milan A, Del Colle S, Pugni C, et al. Heart rate variability and baroreflex sensitivity during fosinopril, irbesartan and atenolol therapy in hypertension. Clin Drug Investig. 2004;24:651-9. [PMID: 17523728] 57. Rajzer M, Klocek M, Kawecka-Jaszcz K. Effect of amlodipine, quinapril, and losartan on pulse wave velocity and plasma collagen markers in patients with mild-to-moderate arterial hypertension. Am J Hypertens. 2003;16:439-44. [PMID: 12799091]

58. Rosei EA, Rizzoni D, Muiesan ML, Sleiman I, Salvetti M, Monteduro C, et al.; CENTRO (CandEsartaN on aTherosclerotic Risk factors) Study Investigators. Effects of candesartan cilexetil and enalapril on inflammatory markers of atherosclerosis in hypertensive patients with non-insulin-dependent diabetes mellitus. J Hypertens. 2005;23:435-44. [PMID: 15662233]

59. Ruilope L, Jäger B, Prichard B. Eprosartan versus enalapril in elderly patients with hypertension: a double-blind, randomized trial. Blood Press. 2001;10:223-9. [PMID: 11800061]

60. Saito S, Asayama K, Ohkubo T, Kikuya M, Metoki H, Obara T, et al.; HOMED-BP Study Group. The second progress report on the Hypertension Objective treatment based on Measurement by Electrical Devices of Blood Pressure (HOMED-BP) study. Blood Press Monit. 2004;9:243-7. [PMID: 15472496]

61. Schieffer B, Bünte C, Witte J, Hoeper K, Böger RH, Schwedhelm E, et al. Comparative effects of AT1-antagonism and angiotensin-converting enzyme inhibition on markers of inflammation and platelet aggregation in patients with coronary artery disease. J Am Coll Cardiol. 2004;44:362-8. [PMID: 15261932] 62. Schram MT, van Ittersum FJ, Spoelstra-de Man A, van Dijk RA, Schalkwijk CG, Ijzerman RG, et al. Aggressive antihypertensive therapy based on hydrochlorothiazide, candesartan or lisinopril as initial choice in hypertensive type II diabetic individuals: effects on albumin excretion, endothelial function and inflammation in a double-blind, randomized clinical trial. J Hum Hypertens. 2005; 19:429-37. [PMID: 15647778]

63. Shand BI. Haemorheological effects of losartan and enalapril in patients with renal parenchymal disease and hypertension. J Hum Hypertens. 2000;14:305-9. [PMID: 10822316]

64. Shand BI, Lynn KL. A comparative study of losartan and enalapril on erythropoiesis and renal function in hypertensive patients with renal parenchymal disease [Letter]. Clin Nephrol. 2000;54:427-8. [PMID: 11105808]
65. Shibasaki Y, Masaki H, Nishiue T, Nishikawa M, Matsubara H, Iwasaka T. Angiotensin II type 1 receptor antagonist, losartan, causes regression of left ventricular hypertrophy in end-stage renal disease. Nephron. 2002;90:256-61. [PMID: 11867945]

66. Townsend R, Haggert B, Liss C, Edelman JM. Efficacy and tolerability of losartan versus enalapril alone or in combination with hydrochlorothiazide in patients with essential hypertension. Clin Ther. 1995;17:911-23. [PMID: 8595643]

67. Uchiyama-Tanaka Y, Mori Y, Kishimoto N, Fukui M, Nose A, Kijima Y, et al. Comparison of the effects of quinapril and losartan on carotid artery intimamedia thickness in patients with mild-to-moderate arterial hypertension. Kidney Blood Press Res. 2005;28:111-6. [PMID: 15741734]

68. Verdecchia P, Schillaci G, Reboldi GP, Sacchi N, Bruni B, Benemio G, et al. Long-term effects of losartan and enalapril, alone or with a diuretic, on ambulatory blood pressure and cardiac performance in hypertension: a case-control study. Blood Press Monit. 2000;5:187-93. [PMID: 10915233]

69. Ruff D, Gazdick LP, Berman R, Goldberg AI, Sweet CS. Comparative effects of combination drug therapy regimens commencing with either losartan potassium, an angiotensin II receptor antagonist, or enalapril maleate for the treatment of severe hypertension. J Hypertens. 1996;14:263-70. [PMID: 8728306]

70. Tikkanen I, Omvik P, Jensen HA. Comparison of the angiotensin II antagonist losartan with the angiotensin converting enzyme inhibitor enalapril in patients with essential hypertension. J Hypertens. 1995;13:1343-51. [PMID: 8984133]

71. Nielsen S, Dollerup J, Nielsen B, Jensen HA, Mogensen CE. Losartan reduces albuminuria in patients with essential hypertension. An enalapril controlled 3 months study. Nephrol Dial Transplant. 1997;12 Suppl 2:19-23. [PMID: 9269694]

72. Amerena J, Pappas S, Ouellet JP, Williams L, O'Shaughnessy D. ABPM comparison of the anti-hypertensive profiles of telmisartan and enalapril in patients with mild-to-moderate essential hypertension. J Int Med Res. 2002;30: 543-52. [PMID: 12526280]

73. Fogari R, Mugellini A, Zoppi A, Marasi G, Pasotti C, Poletti L, et al. Effects of valsartan compared with enalapril on blood pressure and cognitive function in elderly patients with essential hypertension. Eur J Clin Pharmacol. 2004;59:863-8. [PMID: 14747881]

74. Lacourcière Y, Neutel JM, Davidai G, Koval S. A multicenter, 14-week study of telmisartan and ramipril in patients with mild-to-moderate hypertension using ambulatory blood pressure monitoring. Am J Hypertens. 2006;19:104-12. [PMID: 16461201]

75. Mallion JM, Bradstreet DC, Makris L, Goldberg AI, Halasz S, Sweet CS, et al. Antihypertensive efficacy and tolerability of once daily losartan potassium compared with captopril in patients with mild to moderate essential hypertension. J Hypertens Suppl. 1995;13:S35-41.

76. Malmqvist K, Kahan T, Dahl M. Angiotensin II type 1 (AT1) receptor blockade in hypertensive women: benefits of candesartan cilexetil versus enalapril or hydrochlorothiazide. Am J Hypertens. 2000;13:504-11. [PMID: 10826401] 77. Ragot S, Ezzaher A, Meunier A, Poterre M, Bourkaib R, Herpin D. Comparison of trough effect of telmisartan vs perindopril using self blood pressure measurement: EVERESTE study. J Hum Hypertens. 2002;16:865-73. [PMID: 12522468]

78. Roca-Cusachs A, Oigman W, Lepe L, Cifkova R, Karpov YA, Harron DW. A randomized, double-blind comparison of the antihypertensive efficacy and safety of once-daily losartan compared to twice-daily captopril in mild to moderate essential hypertension. Acta Cardiol. 1997;52:495-506. [PMID: 9542575] 79. Williams B, Gosse P, Lowe L, Harper R; PRISMA I Study Group. The prospective, randomized investigation of the safety and efficacy of telmisartan versus ramipril using ambulatory blood pressure monitoring (PRISMA I). J Hypertens. 2006;24:193-200. [PMID: 16331118]

80. Hasford J, Mimran A, Simons WR. A population-based European cohort study of persistence in newly diagnosed hypertensive patients. J Hum Hypertens. 2002;16:569-75. [PMID: 12149663]

81. Franke H. Antihypertensive effects of candesartan cilexetil, enalapril and placebo. J Hum Hypertens. 1997;11 Suppl 2:S61-2. [PMID: 9331010]

82. Robles NR, Angulo E, Grois J, Barquero A. Comparative effects of fosinopril and irbesartan on hematopoiesis in essential hypertensives. Ren Fail. 2004; 26:399-404. [PMID: 15462108]

83. Mazzaglia G, Mantovani LG, Sturkenboom MC, Filippi A, Trifirò G, Cricelli $\mathrm{C}$, et al. Patterns of persistence with antihypertensive medications in 
newly diagnosed hypertensive patients in Italy: a retrospective cohort study in primary care. J Hypertens. 2005;23:2093-100. [PMID: 16208153]

84. Sato A, Tabata M, Hayashi K, Saruta T. Effects of the angiotensin II type 1 receptor antagonist candesartan, compared with angiotensin-converting enzyme inhibitors, on the urinary excretion of albumin and type IV collagen in patients with diabetic nephropathy. Clin Exp Nephrol. 2003;7:215-20. [PMID: 14586718]

85. Grégoire JP, Moisan J, Guibert R, Ciampi A, Milot A, Côté I, et al. Tolerability of antihypertensive drugs in a community-based setting. Clin Ther. 2001;23:715-26. [PMID: 11394730]

86. Mackay FJ, Pearce GL, Mann RD. Cough and angiotensin II receptor antagonists: cause or confounding? Br J Clin Pharmacol. 1999;47:111-4. [PMID: 10073748]

87. Bloom BS. Continuation of initial antihypertensive medication after 1 year of therapy. Clin Ther. 1998;20:671-81. [PMID: 9737827]

88. Bourgault C, Sénécal M, Brisson M, Marentette MA, Grégoire JP. Persistence and discontinuation patterns of antihypertensive therapy among newly treated patients: a population-based study. J Hum Hypertens. 2005;19:607-13. [PMID: 15920457]

89. Conlin PR, Gerth WC, Fox J, Roehm JB, Boccuzzi SJ. Four-Year persistence patterns among patients initiating therapy with the angiotensin II receptor antagonist losartan versus other artihypertensive drug classes. Clin Ther. 2001;
23:1999-2010. [PMID: 11813934]

90. Degli Esposti L, Degli Esposti E, Valpiani G, Di Martino M, Saragoni S, Buda S, et al. A retrospective, population-based analysis of persistence with antihypertensive drug therapy in primary care practice in Italy. Clin Ther. 2002;24: 1347-57; discussion 1346. [PMID: 12240784]

91. Degli Esposti E, Sturani A, Di Martino M, Falasca P, Novi MV, Baio G, et al. Long-term persistence with antihypertensive drugs in new patients. J Hum Hypertens. 2002;16:439-44. [PMID: 12037702]

92. Erkens JA, Panneman MM, Klungel OH, van den Boom G, Prescott MF, Herings RM. Differences in antihypertensive drug persistence associated with drug class and gender: a PHARMO study. Pharmacoepidemiol Drug Saf. 2005; 14:795-803. [PMID: 16178043]

93. Marentette MA, Gerth WC, Billings DK, Zarnke KB. Antihypertensive persistence and drug class. Can J Cardiol. 2002;18:649-56. [PMID: 12107422]

94. Wogen J, Kreilick CA, Livornese RC, Yokoyama K, Frech F. Patient adherence with amlodipine, lisinopril, or valsartan therapy in a usual-care setting. J Manag Care Pharm. 2003;9:424-9. [PMID: 14613440]

95. Burke TA, Sturkenboom MC, Lu SE, Wentworth CE, Lin Y, Rhoads GG. Discontinuation of antihypertensive drugs among newly diagnosed hypertensive patients in UK general practice. J Hypertens. 2006;24:1193-200. [PMID: 16685222]

\section{CME CREDIT}

Readers can get $C M E$ credit for the following: 1) questions from the ACP's Medical Knowledge Self-Assessment Program (MKSAP) related to In the Clinic articles that are published in the first issue of every month, and 2) designated articles in each issue. To access CME questions, click on the CME option under an article's title on the table of contents at www.annals.org. Subscribers may take the tests free of charge. For a nominal fee, nonsubscribers can purchase tokens electronically that enable them to take the CME quizzes.

Reviewers who provide timely, high-quailty reviews also may get CME credit. 
Current Author Addresses: Drs. Matchar, McCrory, Orlando, Patwardhan, Samsa, and Gray: Duke Center for Clinical Health Policy Research, 2200 West Main Street, Suite 220, Durham, NC 27705.

Dr. M.R. Patel: Duke Clinical Research Institute, North Pavilion, 2400 Pratt Street, Room 0311, Durham, NC 27705.

Dr. U.D. Patel: Department of Nephrology, Duke University Medical Center, DUMC Box 3646, Durham, NC 27710.

Dr. Powers: Duke University and Durham Veterans Affairs Medical Center, 2424 Erwin Road, Suite 1105, Durham, NC 27705.

\section{ApPendix 1: Methods for ReVIeWIng IndiRect COMPARISON STUDIES}

Our review of the literature on the comparative long-term benefits and harms of angiotensin-converting enzyme (ACE) inhibitors versus angiotensin II receptor blockers (ARBs) for treating hypertension focused, in the first instance, on direct head-tohead comparisons of drugs in the 2 classes. Because we were uncertain that these direct comparisons would adequately address all aspects of the key questions, we also sought to identify and screen potentially relevant indirect comparison studies-studies in which ACE inhibitors and ARBs were compared, in distinct trials, with a common comparator. This Appendix describes the methods we used to identify and review indirect comparison studies.

\section{Search and Abstract Screening}

We began by searching MEDLINE for studies of ARBs versus other (non-ACE inhibitor) comparators, including placebo. We screened these abstracts along with the head-to-head trials. For indirect comparisons, we considered only randomized, controlled trials. We coded each included abstract for duration of treatment or follow-up (for example, "12 weeks" or "1 year").

Because a primary objective for evaluating non-head-tohead studies was to expand the pool of evidence regarding longterm results, we restricted the pool of abstracts for further evaluation to those with a duration of treatment or follow-up of at least 24 weeks. Further, because the credibility of any meta-analysis-particularly for non-head-to-head trials— depends on consistency among studies, we considered only comparators studied in at least 3 trials. The comparators thus identified were atenolol, amlodipine, and placebo.

Next, we searched MEDLINE for studies of ACE inhibitors versus atenolol or amlodipine. To identify potentially relevant trials of ACE inhibitor versus placebo, we began by searching the references of the June 2005 Drug Class Review on ACE inhibitors (4) and supplemented this with a search of MEDLINE for articles published after that review. Finally, the abstracts for all ACE inhibitor versus other studies of treatments were screened for inclusion and evaluated further to identify trials with the right treatment duration or length of follow-up ( $\geq 24$ weeks) and the right comparators (atenolol, amlodipine, or placebo).

From this process, we identified 76 randomized, controlled trial publications comparing ARBs with atenolol, amlodipine, or placebo over at least 24 weeks, and 136 randomized, controlled trial publications comparing ACE inhibitors with the same group of comparators over the same period. We could not obtain 4 articles ( 2 each for ACE inhibitors and ARBs), so the final counts were 74 potentially relevant ARB articles and 134 potentially relevant $\mathrm{ACE}$ inhibitor articles.

\section{Identifying Publications Reporting Outcomes of Interest}

Once data from the direct comparator trials had been abstracted, we identified 3 categories of outcomes that we thought were underreported in these trials: death and major events (myocardial infarction, stroke), measures of carbohydrate metabolism or diabetes control (progression to type 2 diabetes, hemoglobin $A_{1 c}$, insulin or other diabetes medication dosage, fasting plasma glucose, or aggregated measures of serial glucose measurements), and measures of kidney disease (creatinine level, glomerular filtration rate, and proteinuria). We then screened the indirect comparison literature identified through the process described above in full-text form to identify publications that reported on 1 or more of these outcomes. Thirty-two articles on ARBs versus other therapies and 42 articles on ACE inhibitors versus other therapies reported 1 or more of the outcomes of interest and were evaluated further.

\section{Analysis of Comparability of Trials}

Because of the challenges of using indirect (non-head-tohead) comparison studies to infer relative efficacy regarding any particular health outcome, we established minimal criteria before considering any indirect comparison. Our goal was to achieve a reasonable degree of clinical homogeneity without being excessively restrictive at this stage.

We defined 3 criteria for considering performing an indirect comparison. The first criterion was that the studies must have a common comparator (amlodipine, atenolol, or placebo), because comparators cannot be considered equivalent with regard to any particular health outcome. The second criterion was that study populations must be generally comparable, at least with regard to key characteristics relevant to the outcome being assessed. For studies examining event rates (mortality, stroke, or myocardial infarction), the key characteristic was the mean age of the population. For studies of laboratory measures (hemoglobin $A_{1 c}$, glucose, or creatinine level; glomerular filtration rate; or proteinuria), the key characteristic was the mean of the corresponding laboratory measure at baseline. The value for the key characteristic could be different by as much as $10 \%$ and still be considered comparable (for example, comparable studies for mortality rates in which the study with the highest mean age for patients was 70 years could have mean patient ages as low as 63 years). The third criterion was that among studies satisfying the preceding criteria, there must be more than 1 study of an ACE inhibitor versus the comparator and more than 1 study of an ARB versus the comparator. That is, indirect comparisons for a particular outcome were considered only if we could find at least 4 comparable studies to evaluate, 2 for an ACE inhibitor and 2 for an ARB. Notably, we did not restrict studies to the same ACE inhibitor or $\mathrm{ARB}$, or any other protocol characteristics.

Despite these relatively liberal criteria for considering indirect comparisons between ACE inhibitors and ARBs, we did not identify any appropriate candidate studies related to an outcome of special interest, and thus we did not attempt to use indirect evidence to infer relative effect of ACE inhibitors versus ARBs. 


\section{Appendix 2: Applicability CRITeria}

We did not provide a global rating of applicability (such as "high" or "low") because applicability may differ substantially depending on the user of the review. However, applicability of research studies was assessed by noting the most important potential limitations in a study's applicability from among the list described by Rothwell (24). These criteria, slightly adapted by the Scientific Resource Center, are reproduced below. Assessors were instructed to list the most important (up to 3) limitations affecting applicability, if any, on the basis of this list.

Instructions to abstractors/assessors: Do not assign an overall applicability score. Instead, list the most important (up to 3) limitations affecting applicability, if any, based on the following list.

\section{Setting of the Study}

1. In which country (or countries) was the study conducted?

2. In what health care system (or systems) was the study conducted?

3. Were patients recruited from the primary, secondary, or tertiary care settings?

4. How were study centers selected for participation?

5. How were study clinicians selected for participation?

\section{Selection of Participants}

6. How were participants diagnosed and identified for eligibility screening before random allocation?

7. What were the study eligibility criteria?

8. What were the study exclusion criteria?

9. Did the study require a run-in period with the control or placebo intervention?

10. Did the study require a run-in period with the active intervention?

11. Did the study selectively recruit participants who demonstrated a history of favorable or unfavorable response to drug or other interventions for the condition?

12. Did the study report the ratio of randomly allocated participants to nonallocated participants (who were eligible)?

13. Did the study report the proportion of eligible participants who declined random allocation?

\section{Characteristics of Study Participants}

14. Did the study report participants' baseline characteristics?

15. Did the study report participants' race?

16. Did the study report participants' underlying pathology?
17. Did the study report participants' stage in the natural history of the disease?

18. Did the study report participants' severity of disease?

19. Did the study report participants' comorbid conditions?

20. Did the study report participants' absolute risk of a poor outcome in the control arm?

\section{Differences between the Study Protocol and Routine Clinical Practice}

21. Were the study interventions (active arm) similar to interventions used in routine clinical practice?

22. Was the timing of the intervention similar to the timing in routine clinical practice?

23. Was the study's control arm appropriate and relevant in relation to routine clinical practice?

24. Were the study's co-interventions-which were not randomly allocated - adequate to reflect routine clinical practice?

25 . Were any interventions prohibited by the study that are routinely used in clinical practice?

26. Have there been diagnostic or therapeutic advances used in routine practice since the study was conducted?

\section{Outcome Measures and Follow-up}

27. If applicable, did the study use a clinically relevant surrogate outcome?

28. If applicable, did the study use a scale that is clinically relevant, valid, and reproducible?

29. If applicable, was the intervention beneficial on the most relevant components of the composite outcome?

30. Which clinician measured the outcome (e.g., treating physician or surgeon)?

31. Did the study use patient-centered outcomes?

32. How frequently were participants followed in the study?

33. Was the duration of participant follow-up adequate?

\section{Adverse Effects of Treatment}

34. How completely did the study report the occurrence of relevant adverse effects?

35. Did the study report the rates of treatment discontinuations?

36. Were the study centers and/or clinicians selected on the basis of their skill or experience?

37. Did the study exclude participants at elevated risk of intervention complications?

38. Did the study exclude participants who suffered adverse effects during the run-in period?

39. Did the study monitor participants intensively for early signs of adverse effects? 